\title{
DIFFERENTIATION OF THE SIBLING SPECIES BIOMPHALARIA OCCIDENTALIS AND BIOMPHALARIA TENAGOPHILA BY THE ELECTROPHORETIC PATTERNS OF THEIR HEMOGLOBIN*
}

\author{
JAMES B. BAILEY** EDWARD H. MICHELSON** \& W. LOBATO PARAENSE **
}

A simple and rapid method for differentiating the sibling species Biomphalaria tenagophila and Biomphalaria occidentalis by agarose gel electrophoresis ( $A G E$ ) is described. Snail hemolymph is used as the test sample and the red coloration of the hemoglobin fraction permits visualization of the migration patterns without resorting to specific stains. Moreover, hemolymph samples may be obtained without killing the snail, thus permitting its use for other studies or for breeding.

Key words: Biomphalaria occidentalis - Biomphalaria tenagophila - sibling species - hemoglobin - electrophoresis - biochemical taxonomy

In 1981, Paraense described Biomphalaria occidentalis, a species which could not be differentiated from Biomphalaria tenagophila by shell characteristics or by the morphology of most of the genital organs. In the laboratory, the two species were found to be reproductively incompatible and consequently may be considered sibling species. Differentiation of the two species can be accomplished only by careful dissection of the male and female genitalia and the demonstration of the presence of a vaginal pouch in $B$. tenagophila and its absence in $B$. occidentalis. There are, in addition, morphometric differences in the prepuce/penile sheath complex of the two species. Differentiation, therefore, is a highly complex process requiring a high level of skill in dissecting these organisms and rigid control of relaxation and fixation of the snails.

$B$. tenagophila is a recognized host of Schistosoma mansoni, whereas B. occidentalis appears to be a non-susceptible species (Paraense \& Correa, 1982). The need for a method, less tedious than manual dissection, to differentiate the species is obvious.

A technique employing snail hemolymph and agarose gel electrophoresis (AGE) for the differentiation of the two species is described. The technique has been found to be simple, rapid, repeatable, cost effective and suitable for rural laboratories.

\section{MATERIALS AND METHODS}

Six strains of $B$. tenagophila and four strains of $B$. occidentalis, all from Brazil, were used in the study (Tab. I). Maintenance of the snail populations was as previously described (Michelson, 1966).

Two methods were used for collecting hemolymph. When large amounts of hemolymph $(50-100 \mu 1)$ were required and snails were expendable, hemolymph was collected from the pericardial cavity as described by Michelson (1966). If snails were required for breeding or for other studies, hemolymph was drawn by puncturing the mantle collar with the tip of a sharp forceps and collecting the pooled fluid with a fine-tipped micropipet. Approximately $10-50 \mu 1$ of hemolymph could be obtained with this method and snail mortality was generally less than $10 \%$.

Fresh hemolymph was mixed in a proportion of $5: 2$ with a sample solution comprised of $80 \%$ glucose containing $5 \%$ glycerol and sufficient $0.5 \%$ bromphenol blue to give a dark purple color. Ten microliters of the mixture were used as the sample for agarose gel electrophoresis (AGE). AGE was conducted in either Mini-vertical or Mini-subhorizontal cells (Bio-Rad Laboratories) and both methods gave comparable results; however, the vertical system appeared to give sharper bands. In both systems, the gel matrix consisted of $0.8 \%$ agarose in $0.15 \mathrm{M}$ tris-borate buffer, pH 8.5. Although we used an ultrapure DNA grade agarose (Bio-Rad Laboratories), pre-

* The opinions or assertions contained herein are the private ones of the authors and are not to be construed as official or reftecting the views of the Department of Defense or the Uniformed Services University of the Heal th Sciences. The investigation received support from an institutional grant awarded by the Uniformed Services University of the Heal th Sciences.

* Department of Preventive Medicine and Biometrics, Uniformed Services University of the Health Sciences, 4301 Jones Bridge Road, Bethesda, Maryland 20814-4799, U.S.A.

** Instituto Oswaldo Cruz, Departamento de Malacologia, Caixa Postal 926, 20001 Rio de Janeiro, RJ, Brasil. Received for publication January 27 th and accepted March 27 th, 1986. 
TABLE 1

Species and the geographic origin of strains from which hemoglobin was obtained*

\begin{tabular}{|c|c|}
\hline Species & Geographic Origin \\
\hline Biomphalaria occidentalis & $\begin{array}{l}\text { Barão de Melgaço, Mato Grosso } \\
\text { Guaira, Paraná } \\
\text { Valparaíso, São Paulo } \\
\text { Sena Madureira, Acre }\end{array}$ \\
\hline Biomphalaria tenagophila & $\begin{array}{l}\text { Joinville, Santa Catarina } \\
\text { Rio de Janeiro, RJ } \\
\text { Brasília, D F } \\
\text { Taubaté, São Paulo } \\
\text { São José dos Campos, São Paulo } \\
\text { Vitória, Espírito Santo }\end{array}$ \\
\hline
\end{tabular}

*All snail populations were derived from those maintained by Dr.W.L.

Paraense, Instituto Oswaldo Cruz, Rio de Janeiro.

liminary studies demonstrated that less chemically pure agaroses would suffice. Horizontal gels, $2 \mathrm{~mm}$ in thickness, were prepared by pouring $15 \mathrm{ml}$ of melted agarose directly onto a Gel Bond $(\mathrm{R})$ sheet (FMC BioProducts), $6.4 \mathrm{~cm} \times 11.0 \mathrm{~cm}$, containing a $10 \mathrm{comb}$ well-spacer situated $1 \mathrm{~cm}$ from a smaller edge. The gels were cured for $2 \mathrm{hr}$ at $5{ }^{\circ} \mathrm{C}$ before use and $\mathrm{AGE}$ was run at $104 \mathrm{~V} / 70 \mathrm{~min} /$ $25^{\circ} \mathrm{C}$. Vertical gels, $1.5 \mathrm{~mm}$ in thickness, were prepared in a casting cell and used approximately $9.3 \mathrm{ml}$ of agarose to make a gel $8 \mathrm{~cm}$ wide $\times 7 \mathrm{~cm}$ long. Gels were run at $104 \mathrm{~V} / 55 \mathrm{~min} / 25^{\circ} \mathrm{C}$. Routinely, ten sample wells were cast; however, the number may be varied to suit the needs of the investigator.

After electrophoresis was completed, gels were fixed in $12 \%$ acetic acid containing $5 \%$ glycerol for $1 \mathrm{hr}$ or until the bromphenol marker was no longer visible. Gels were then rinsed in deionized water and those run in a vertical cell were now mounted onto Gel Bond sheets. Permanent preparations were made by dehydrating the gels to a thin layer in accordance with the technique described by Saravia \& Cook (1979). This consisted in covering the gels with a moist piece of filter paper, adding several layers of absorbent paper toweling, then placing an evenly distributed weight of $2 \mathrm{~kg}$ on top of the gel-paper complex. After $30 \mathrm{~min}$, the weight and the papers were carefully removed and the film further dried in a $37 \mathrm{O}^{\circ} \mathrm{C}$ incubator for $4-6 \mathrm{hr}$ or held overnight at room temperature. Stain was not required as the red-colored hemoglobin bands were clearly visible. The preparations may be photographed or photocopied and the gel films can be stored indefinitely.

Migration distances were determined by noting the distance of the bands from the point of origin; however, $R f$ values could be determined also in relation to the bromphenol dye front.

\section{RESULTS}

Our results indicated that the hemoglobin portion of B. occidentalis hemolymph migrated faster than did that of $B$. tenagophila. In most runs the bands were separated by a distance of $1.2 \mathrm{~mm}$. Although some variation in absolute distance was noted between runs, the distance between the bands of the two species did not show appreciable variation. No differences were noted among the geographical strains of the same species. Variation appeared to be less in gels run in the vertical system than those done in the horizontal system.

In the 62 analyses done in the horizontal system, the hemoglobin band of $B$. occidentalis migrated at least $1 \mathrm{~mm}$ farther than that of $B$. tenagophila in 55 comparisons (Fig. 1 A). In five sample runs, the hemoglobin of the two species migrated equally or so closely to one another that they could not be differentiated. Only two sample runs were observed in which the $B$. tenagophila band migrated faster than its sibling species.

In all of the 42 analyses done in the vertical system, B. occidentalis hemoglobin migrated at least $1 \mathrm{~mm}$ farther than did the hemoglobin of $B$. tenagophila (Fig. 1B). When the results from both systems were combined, it was found that $B$. occidentalis hemoglobin migrated faster than $B$. tenagophila $93.3 \%$ of the time, migrated at an equal rate with the latter species $4.8 \%$ of the time, and had a slower migration $1.9 \%$ of the time. 


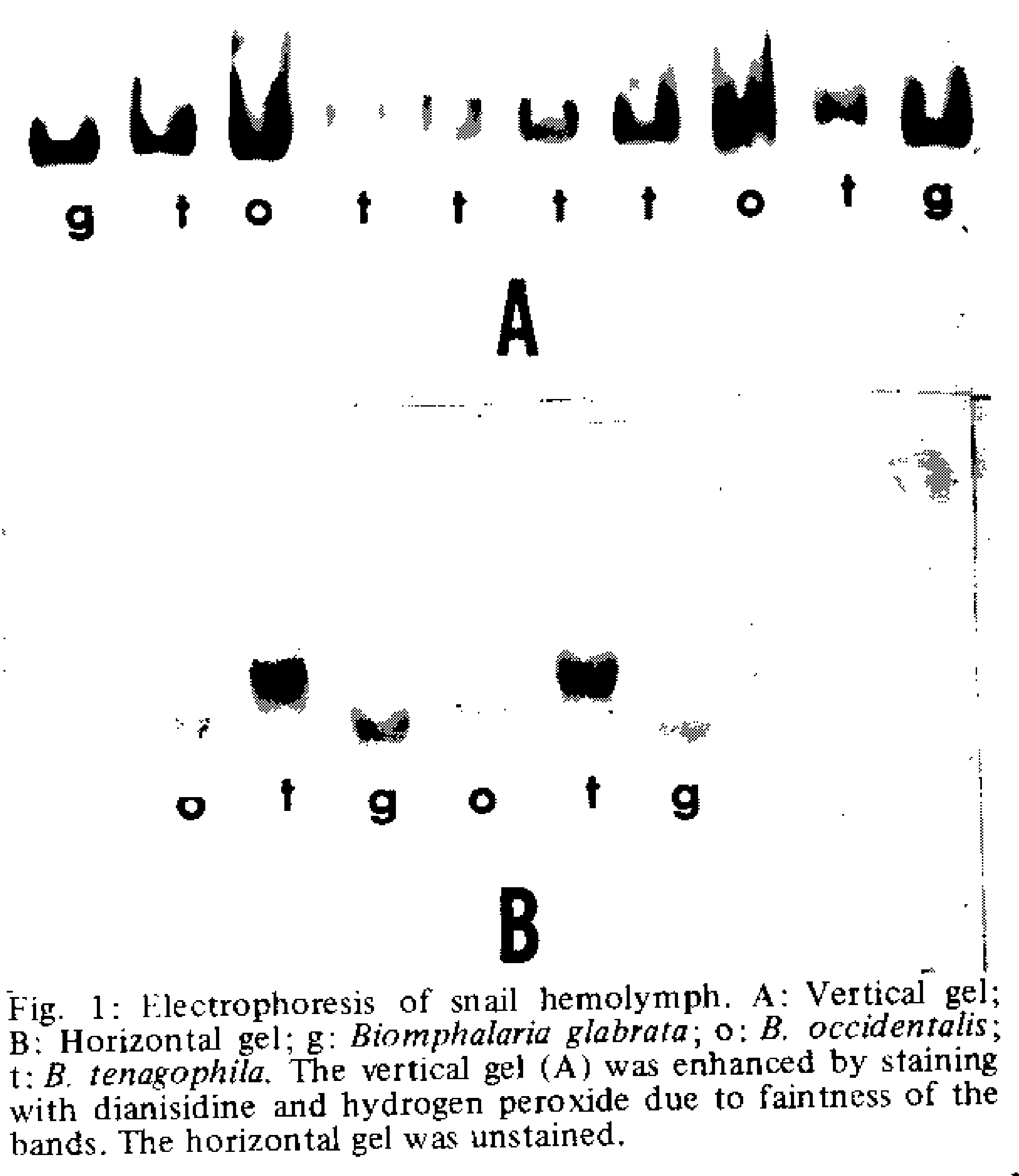

A limited number of experiments demonstrated that $B$. glabrata and B. straminea, both intermediate hosts of $S$. mansoni in Brazil, had hemoglobins which migrated faster than $B$. occidentalis; however, the two species could not be separated from one another in the present system.

\section{DISCUSSION}

Efforts to use hemolymph from species of planorbid snails as a taxonomic tool are not new and have been reviewed, in part, by Michelson (1973) and by Wright $(1971,1974)$. In past studies, electrophoretic analyses of hemolymph had been directed towards demonstrating differences in protein and isozyme patterns. Wright (1971) questioned the value of these techniques for taxonomic studies since he observed both quantitative and qualitative variations associated with age and/or size of individual snails. Subsequently, tissue extracts have replaced hemolymph as the sample of choice in applications of electrophoresis for taxonomic purposes.

The present study, however, demonstrates that the analyses of snail hemolymph hemoglobins by AGE may be a valuable adjunct to existing techniques for species identification. In Biomphalaria species, hemoglobin is a major constituent of the hemolymph and in some species may constitute as much as $40-65 \%$ of the total protein concentration (Michelson \& Dubois, 1975). The hemoglobin fraction in these snails is characterized by being chromogenic, non-corpusculat, and of high molecular weight $\left(1 \times 10^{6}\right.$ or greater $)$. Specific differences in hemoglobin mobility were not apparent in past studies, since the matrices employed for electrophoresis prevented or limited the migration of these molecules. AGE separates protein molecules by both charge densities and molecular seiving and, at concentrations of $0.6-0.8 \%$, gels have pore sizes adequate for the migration of snail hemoglobins.

Our results indicate that differences in hemoglobin migration was a reliable criterion for separating the sibling species $B$. occidentalis and $B$. tenagophila, separation being demonstrated in $93.3 \%$ of the test samples. In addition, the mini-system has several advantages: (1) it permits the test snails to remain alive for use in other studies; (2) results are rapid; (3) the technique is simple and requires no special skills; (4) migration patterns can be demonstrated without the use of special stains or substrates; and (5) the method is relatively cheap, both in actual cost (estimated at \$0.03-\$0.08/sample) and materials required. Preliminary experiments suggest that the technique may be applicable to other groups of hemoglobin-bearing snails, and recent studies with African planorbids appear promising. 


\section{RESUMO}

É descrito um método simples e rápido para distinguir as espécies crípticas Biomphalaria tenagophila e $B$. occidentalis por eletroforese em gel de agarose. A prova é feita com hemolinfa do molusco, permitindo a cor vermelha da fração hemoglobina visualizar os padrōes de migração sem necessidade de recorrer a colorações específicas. Além disso, as amostras de hemolinfa podem ser obtidas sem sacrificar o molusco, que poderá ser usado para outros estudos ou para criação.

\section{REFERENCES}

MICHELSON, E.H., 1966. Specificity of hemoly mph antigens in taxonomic discrimination of medically important snails. J. Parasitol., $52: 466-467$.

MICHELSON, E.H., 1973. Electrophoretic techniques in malacology: applications and pitfalls. Malocol. Rev., 8 $: 44-47$.

MICHELSON, E.H. \& DUBOIS, L., 1975. Intraspecific variations in the hemolymph of Biomphalaria glabrata, a snail host of Schistosoma mansoni. Malacologia, 15:105-111.

PARAENSE, W.L., 1981. Biomphalaria occidentalis sp.n. from South America (Mollusca Basommatophora Pulmonata).Mem. Inst. Oswaldo Cruz, $76: 199-211$.

PARAENSE, W.L. \& CORRÊA, L.R., 1982. Unsusceptibility of Biomphalaria occidentalis to infection with a strain of Schistosoma mansoni. Mem. Inst. Oswaldo Cruz, 77 :55-58.

SARAVIA, C.A. \& COOK, R.B., 1979. Agarose isoelectrofocusing with IsoGel agarose and Gel Bond film. FMC Corp., Rockland, Maine, 17 pp.

WRIGHT, C.A., 1971. Flukes and Snails. George Allen and Unwin, Ltd., London..

WRIGHT, C A., 1974. Biochemical and immunological taxonomy of the Mollusca. In: Biochemical and Immunological Taxonomy of Animals, ed. C.A. Wright, Acad. Press, N.Y., pp. 351-385. 